\title{
Gender Dynamics in Athol Fugard's Drama
}

\author{
Margaret Njoki Mwihia \\ School of Education, Mount Kenya University \\ njokimwihia@yahoo.com
}

Wallace K Mbugua

Kenyatta University

\section{Doi:10.5901/mjss.2014.v5n5p}

\begin{abstract}
After reading most of Fugard's plays, the reader will notice that Fugard indirectly describes the struggle of the female gender during dramatic events in his plays. For instance, in his play, The Island, Fugard has dramatised the humiliation and struggle of a woman. The playwright presents us with characters who try to cope with the degrading condition of prison. Both make do with the situation but Winston cannot help but express his frustration on the deprival of sex. This clearly demonstrates that women have been relegated to a lesser position of being objects of pleasure in South Africa.
\end{abstract}

Keywords: Gender, Drama, Literature, Play

\section{Background}

Works of critics who have studied Fugard's plays and those reviewers who have done some reviews of his plays have been examined as a way of finding out gaps that the current research aims at filling and also as a means of augmenting our argument. Osundare $(2000$, p. 20$)$ in an interview notes the inter-relationship between literature and the society. $\mathrm{He}$ states the following:

\begin{abstract}
We have to stress this, because we live in a world in which in some parts at the end of the twentieth century, people just think that Literature doesn't matter. They have forgotten that Europe and America wouldn't have developed to the state that they are now without the works of Homer, without the works of Virgil, without the works of Chaucer and Shakespeare. All these works prepare the minds of the people, sharpened and refined their sensibility. I don't know whether there would be any science if there hadn't been literature.
\end{abstract}

The above observation indicates that there is a relationship between literature and the society. Literature is a product of society. It points out how sensitive literature is to the society in recording events and situations through language, and also as an agent of promoting development by propagating social values. This is what Wastberg (1988, $\mathrm{p}$. 20) means when he writes, "a writer is a connoisseur of power. In his very profession lies power to influence." A writer cannot stand aloof to his/her social realities. The recognition of this truism makes it necessary for scholars of literature to study not only the relationship between literature and society but more important the artistic judgment in works of art.

Kirsten (1988 p. 9) reports that Wole Soyinka in his submission to the Second African Writers' Conference asked the writer to be true to his heritage, which as he states is to be not just 'the recorder of the moves and experience of his society,' but also 'the voice of vision in his own time'.In regards to the study's topic in the realm of social vision, Soyinka further observes that the author must not content himself with chronicling the customs of society. "He must play the part of bard and oracle, he must see more clearly and exactly than other people, he must be a visionary, a warning voice and a builder of the future." (quoted in Kirsten 1988, p. 9). This study examines Athol Fugard's drama in terms of how it communicates the playwright's vision.

Wanjala(1970) says of literature "Literature influences life of people and reflects tensions within groups as well as within individuals. It also uses imagination." The term literature is best described as imaginative literature. Language therefore becomes very central in literature. Literature is a social phenomenon i.e. it has a social meaning whether the author be aware of it or not. The creation of literature becomes a social art because creativity is a highly complex organization of character with multiple meaning and relationships. Wanjala's observation gives us more insight into the 
nature of literature and the relationship between literature, society and the writer.

In an essay on John Keats (1795-1821) Paul de Man indirectly shows the link between literasture and the artist. He suggests that Keats should be regarded as a prospective writer unlike William Wordsworth (1770-1850) whose work is retrospective. According to de Man Keats' work 'consist of hopeful preparations, anticipations of future power rather than meditative reflections on past moments of insight and harmony'( cited in Royle 2003, p.103). De Man suggests that Keats' work has a future vision.

De Man's view of Keats seems to us a particularly attractive finding, and one which stands African literature in good instead. Arguing for greater concern with the future in African writing will be the main thrust of our effort here. The tradition among the great majority of African writers to undertake a curative pilgrimage into their society's past has come to be viewed as self-evident. That return seems to be validated by no other reason than that Africa needs to redeem its shattered past, a consensus having been reached that Prospective Commitment in African Literature.

Soyinka's cautionary note alerts the modern consciousness to a totally different reality. That the African past deserves attention is in no doubt. But what should be the focus of that attention has continued to generate quite some controversy. The dominant view, ever since Achebe's ground-breaking novel Things Fall Apart holds western civilization responsible for the African predicament. This view sanctifies the African past, makes of it a venerable age of great achievements and entente, then indicts European explorers for abruptly and in certain cases brutally bringing that great age to an end. The need is felt, therefore, to chronicle the disintegrative process with a view to restoring the grandeur of old.

This exercise in clinical historiography Soyinka condemns. And his position situates itself on a road travelled earlier by the likes of T.S. Eliot. Among the many insights with which the latter mind has studded the landscape of modern thought belongs his view of contemporary history as an immense panorama of futility and anarchy (Kermode 1975: 177). Eliot was a scholar of anarchy, reader of a world ordered by chaos and meaninglessness, of which The Waste Land constitutes the finest poetic epitome. Eliot's essential nihilism was suggested to him by humanity's track record, bleak and chaotic in the main. He looked around him into the prime movers of human action and discovered that only very rarely did man dedicate himself to the welfare of his species. This discovery, however, did not dull his optimism. He nurtured the hope that the chaos could be defeated, basically through a continuous exploitation of the parallel between contemporaneity and antiquity. He saw in a structural awareness of this kind the best means of giving shape and significance to history, the responsibility for such a task lying ideally with the writer, whose powers of constructive retrospection would invest history with a new role, that of wellspring of human valor.

Writing much later in the day, but in the footsteps of his English predecessor, Nkosi (1981: 32) also views history as "a conspiracy of malevolent forces." And just like Eliot, he ascribes to the writer a redemptive mission: "Out of the raw materials of history the novelists construct for us 'fictions'; in so doing they create patterns of meaning out of a jumble of meaningless chaos" (Nkosi 1981: 31-32). Nkosi's observation is significant to this study because our focus in on how Fugard fuses history into his drama and ends up communicating his vision on Apatheid South Africa.

What Eliot calls shape and significance, and Nkosi patterns of meaning are redeeming strengths that underline history's ability to wrest itself from chaotic negativity and transform into source material for human worth. History incessantly confronts the writer with a jumble of meaningless chaos. His duty is now to extract from this jumble, such elements as can restore meaning to existence, now and tomorrow, and to craft such elements into works for the vivification of his society. Thus the African writer cannot just document African history but be selective and artistically reveal his/her vision. Ngugi Wa Thiongo (1993, p.50) succinctly:

I believe that African intellectuals must align with the struggle of the African masses for meaningful life. For we must strive for a form of spirit and energy of our people and a new country, and sing a new song. Perhaps, in a small way, the African writer can help in articulating the feeling beyond this struggle

It has been established that Fugard has articulated the feelings of the readers through the characters as Ngugi(1981,p.80) also argues in Writers in Politics that a writer must 'Show commitment' to the 'actual struggle of the African people'. In his collection of essays in Homecoming, (1972, p.47) Ngugi perceives an artist's literary works as reflecting his experiences as well as those of the society from which he lives. Fugard has communicated his feelings as well as experiences through those characters that have been established to carry his social vision in the four plays.

Fugard's works have received some criticism from researchers and critics of South African Literature. Wertheim (2000,p.1) states that his own study on Fugard's dramatic art is meant to be a discussion on all his plays on what is called 'the playwright as a thinker' and he examines Fugard's ideas for a modern theatre audience. This study is justified in that it focuses on Fugard's social vision for all the races regardless of age, gender and the way he communicates it through 
four selected plays. It critically examines how the playwright prepared his audience for transition in his social vision. Although these plays were set decades before the demise of apartheid at a time when the racial segregation law was in place, it has been found to be essential to examine them to establish how Fugard addresses the issue of apartheid and his vision of redemption amidst opposition. It was not easy for Fugard to communicate his vision as the apartheid law did not allow the races to interact. "True enough Alan Paton cannot travel abroad nor can the playwright Athol Fugard"(Mphalele 1972, p. 214).According to the apartheid laws, the races were not supposed to relate socially, so as aid earlier, when Fugard opposed the regime through his art, he was denied travelling outside South Africa. Anyone who spoke for the rights of the black race received a negative response from the regime. Mphalele (1972, p. 214) also states that Alan Paton like Athol Fugard, was a white South African novelist who was also denied travelling due to producing works that castigated the apartheid system.. This study establishes how Fugard's social vision emerges in the plays despite the odds.

Fugard was opposed by his own race as well as by the blacks he wsa fighting for. "Fugard's dilemma had often been and would continue to be, that of being taken to task for writing about the degradation of the black and the coloured people while he himself was afforded the privileges enjoyed by South African whites". (Wertheim 2002, p.2) This explains the opposition he got from his own race. At the same time, his skin colour deprived him of complete acceptance by the blacks he was fighting for because they saw him as a white man whose skin was their deprivation. The blacks most likely saw Fugard as necessarily seeing the life of the blacks and the coloureds at a distance. "This always kept him from truly understanding what it was to be a 'non-white' in South Africa and also what it was like to live in blows that only blacks and coloureds knew of with terrible immediacy"(Wertheim (2002, p.2).

In his introduction, Fugard (1987) says that when his play Blood Knot was staged on television by the British Broadcasting Co-operation (BBC), his passport was confiscated so that he could no longer travel abroad. This shows that he was trapped between the two conflicting races in his country. By virtue of his colour he could enjoy freedom of movement and expression but on the other hand he disliked the apartheid system that separated South African blacks from enjoying the same freedom the whites enjoyed. It was only because of the privilege of his white skin that his works as well as those of other whites were not banned although the message in them was against racial segregation and the apartheid regime. This was different for the black writers addressing the same issues as Mphahlele (1972,p. 206) explains that he himself with other black and coloured writers including Alex La Guma another non-white South African novelist had to leave South Africa as they were declared prohibited immigrants in South Africa.

These situations are as Tyson (2006, p. 54) suggests: "From a Marxist perspective, differences in socioeconomic class divide people in ways that may be much more significant than differences in religion, race, ethnicity, or gender. This applies not only to South Africa but also to other nations of the world considering that literature is universal. Vices may not necessarily emanate from racism like in the case of South Africa but could also apply to any other causes like social class, economic status or ethnicity which could be found anywhere else in the world. The study has done a critical examination of Athol Fugard's social vision for the South Africans regardless of their skin colour.

On the other hand the black scholars were preoccupied in looking at literary works by non-whites because they had no trust for the whites due to the way they suffered under them. In this way, the blacks who ought to have supported him left his works out due to mistrust. This mistrust among the blacks and whites is a major vice in South Africa brought about by racial segregation. Mphahlele (1972, p.214) asserts:

As long as a white man speaks up for this underdeveloped person; it is not bad...Paton's books are not banned, nor Fugard's plays.

It is therefore evident that Fugard's works also missed considerable attention from African critics due to his colour as opposed to the black and coloured writers of his time (Gachukia (1978, p.214). Alex La Guma a coloured South African writer is an example who got attention from Duerden (1972); Rive (1963); Parker (1978); Abrahams (1972) to mention a few. A black man who wrote the same things the liberal-minded among the whites wrote and represented the same liberal and egalitarian ideas would most likely lead to his exile.

\section{Critical works on Fugard's drama}

As a prolific artist, Athol Fugard has received his share of critical attention. However most of it is in form of interviews, essays, articles in journals and on the internet. Albert Wertheim has however written a whole text The Dramatic Art of Athol Fugard (2000) and examines many of Fugard's plays as he states: "The study of Fugard's dramatic works is meant to be a discussion of all his plays to date focusing on the playwright as a thinker" (Wertheim 2000, p. ix). He examines 
Fugard's ideas as well as his ability to use the dramatic form in order to give shape to his ideas, present them alive and make them alive on stage for modern theatre and audiences. In his research on Athol Fugard's dramatic art, he sees the art generally as a chronicle of South Africa in decades of apartheid and after. He begins from the earliest text Klaas and the Devil (1956) all through to the recent one The Train Driver (2010).

Included in the collections are the texts of this study and he gives some analysis but does not go into the details about either Fugard's vision or preparation for the new era that came with the historical release of Nelson Mandela. He tells about how Athol Fugard and his black friend Mokae starred as the actors Morris and Zachariah in Fugard's The Blood Knot (1962) which was later revised as Blood Knot (1987). He just retells the story as he also does for The Island (1972) but elaborates that this play was inspired by a true story based on the South African notorious Robben Island where Nelson Mandela was held prisoner for twenty seven years. He explains that Fugard's first plays No Good Friday (1958) and Nongogo_(1959) were both set among Sophia Town blacks and they weave together the realism or naturalistic setting of a township. He observes that the characters face the same issue which is the poverty imposed on the blacks of South Africa and that to be black in South Africa is to be poor. This observation is important in this study in that it identifies there is a racial gap in the characters that needs to be examined in search of Fugard's social vision. He explains the importance of Fugard's work as not only for launching his career as a highly regarded playwright but as a signifier in the development of his thinking and theatrical style. However there is no mention of the social vision he has and hence the reasons for this research study to examine it.

Wertheim also posits that Blood Knot (1978) as well as Hello and Goodbye (1965) which are two texts of this study were both Port Elizabeth plays that took place in single rooms but he does not discuss anything about Fugard's vision for the characters. He however observes that they both attacked apartheid which is in the interest of this study. In another play, known as Statement_(1974) he states that the audience is forced to confront the effects of South African law prohibited sexual relationship and marriage between members of different races. In yet another text, Fugard's Master Harold and the Boys (1982) and another one though not one in the study, A lesson From Aloes (1972), he states that Fugard needed to bring together an understanding of interpersonal psychodynamics with the question of race, an amalgam that characterizes the two plays. This is in line with the study in dealing with the characters socially and psychologically. He describes Road to Mecca (1984) as a difficult play and one that resonates at many levels using the drama to contemplate the nature of art and the artist. He suggests that the answer to South Africa's vexing social problems which are very much the product of conservative Afrikaner intransigence will be found by marrying that very stubbornness and tenancy to an inspired vision of freedom. He however does not show how Fugard's vision prepares his characters for that marriage.

Even when he expresses how A place With the Pigs (1987) deals with either remembered incidents or with the painfulness of the present, it is without any mention of Fugard's vision. With another one of Fugard's plays written later, My Children My Africa (1989) Wertheim explains that there is recognition that apartheid days are numbered and a new generation of young people, black and white, stand on the threshold of the future without also a mention of the vision which is the interest of this study. He argues that the play Dimetos (1978) goes to the heart of an essential matter that arises time and again in Fugard's works including the plays of this study. This is the connection between the making of theatre and the making of life, and between the art of theatrical acting and life itself. This shows Wertheim's concern for the dramatic art. However for this study, the main concern is the social vision and preparedness for the characters to adopt an apartheid-free life.

Gray (1982, P.1) states that: "Although Fugard is a well known contemporary dramatist there were relatively few studies covering the entire spectrum of his work." As for another text of the study Hello and Goodbye (1965), he retells the story. He also does the same for the other plays of this study Master Harold and the Boys (1982) which was first produced at Yale repertory theatre in (1982) but was banned in South Africa. The reason Gray gives is that critics focus only on individual plays and Fugard's biography. He states that he himself has done two of his most informative books on Fugard and they are no more than collections of reviews, interviews and essays. In some of the collections by Stephen Gray in the year (2008), he describes Athol Fugard as a South African writer who attacked the apartheid system in his works. Gray narrates the life story of Fugard from his birth and goes on to tell about his works but has no mention of the playwright's social vision thus justifying the need for this research study.

MacDonald (2002) and McLuckie (2003) also have looked at some of Fugard's plays and they describe him as a dramatist of enormous power who uses a small cast. Their focus is on the drama but again they do not talk of the social vision. February $(1981$, p.69) states that Athol Fugard in The Blood Knot (1963) which was the first version of his other title where the article 'The' is removed to read as Blood Knot (1978) which is one of the texts of this study, portrays a realism in which the non-white is at least a victim of the system's ascribed roles. For this study, the interest has been on both the non whites and the whites and what vision the playwright has for them. 
As regards Fugard his influence is as Per Wastberg in the Introductory Essay quoted in Criticism and Ideology: Second African Writers' Conference Stockholm 1986 where he observes that South African scholars have tried to address the problem of censorship, and although they agreed that censorship had recently become less harsh they also agreed that things in general had become worse. Some of the numerous numbers of articles about Athol Fugard's plays that have been recorded in journals are Stephen Holden's fifty six articles in the year 2011. They have information on the politics of Fugard's works. A Journal article by Don MacLennan 'A tribute for Athol Fugard at sixty' has information about Fugard's works as a playwright, novelist, actor director and recipient of many awards.

\section{An Overview of Athol Fugard's Drama}

\subsection{Blood Knot}

In Fugard's Blood Knot the playwright begins by expressing the situation of the blacks in South Africa.

(...)In 1958 the second year of our marriage, we moved to Johannesburg, where I found a job as a clerk in the commissioner's court...Every black man and woman had to carry a pass - book, the endorsement which decides where he may live, work, travel etc. Any violation of this endorsement is a statutory offence and is dealt with in a Native Commissioner's court. The usual sentence is about two week's imprisonment (1987, p. v).

Here we learn that there are two entities. The whites have the upper hand as they are the ones punishing those blacks who go against the pass law while the blacks are the ones who are being oppressed by the pass law. The pass law is meant to control and restrict the blacks in their own land as Durosimi and Jones (1996) states. This is a matter that has also been established in the in the four plays. In Blood Knot Zachariah the black person works as a sentry at a factory gate where he is confined to a standing position daily. Zachariah's feet get sore and swollen as a result of standing in the same position for too long. However he can't vacate the job because he is restricted to move elsewhere by the pass law. Zachariah's boss is not willing to change his position for another because he looks down upon the blacks.

Fugard doesn't stay long in his clerical job as he later gets himself into writing plays drawing his material from what he sees in the slums when he visits his friends. He addresses the ills done to the blacks by the whites in his four selected plays. It has been established that he doesn't like the way the blacks are treated through the roles he gives to his characters. He vents his feelings through his characters. He gives his black characters the disadvantaged roles making the audience sympathize with them. The white characters on the other hand are given negative roles that make the audience feel alienated to them. The audience feels pity for Zachariah as he is made to stand at the gate for long hours so that his feet are swollen. The employer ignores Zachariah's plea for a change of job and also torments him. This is expected to brew hatred from the workers towards the employer as a result of the animosity bestowed on Zachariah. Each race would want to identify with their person and the result is alienation between the blacks and whites. The blacks are expected to identify with Zachariah and harbour some grudges against the whites who are the employers. Fugard's social vision is for the people of South Africa to live like brothers.

Wertheim (2000, p.2) earlier suggests that the playwright sees the lives of the blacks and coloureds at a distance as he is advantaged by his colour which amounts to superiority in South Africa. This however does not blind him from seeing the evils committed by his race against the blacks. He points out the fact that because his colour allows him the freedom to write, Athol Fugard continues writing amounting to the advantage of his social vision. His race however doesn't like his works for the reason that they unearth the situation of the colour discrimination in South Africa but he is not discouraged therefore he continues writing. Morris has pity for his brother and keeps on urging him to ask the boss to change his job for another convenient one but it is all in vain. The boss is not ready to listen to Zachariah's grievances because he is a white and Zachariah is black. Morris like Fugard has pity for his black brother but there is nothing he can do but hope that one day things will change and the whites will be human to the blacks.

Fugard is trapped between his love for humanity and his race. Although he as a white enjoys the freedom of movement and expression, he doesn't like the way his people treat the blacks. The playwright however is a white and there are some privileges that he enjoys because of his colour unlike the black writers. Mphahlele $(1972$, p.214) argues that black writers like Alex La Guma and himself among others had to flee South Africa and go to exile because of addressing the same issues that white writers like Alan Paton, Nadine Gordimer and Athol Fugard among others continued to write about in freedom. In emphasizing this fact, Mphahlele adds that Alan Paton the writer of Cry the Beloved Country criticizes apartheid through his black and white characters and still enjoys a home in South Africa. He 
also cites another white writer Nadine Gordimer in her numerous number of novels as also attacking apartheid but is still comfortably living in South Africa while the black writers have to flee for dear life. However, like Fugard she is also opposed to apartheid. In one of her texts A World of Strangers (1958,p.36) Gordimer states that she wants a South Africa where she can take care of her own relationships and associate with whomever she chooses. She despises the politics of colour. It is then evident that the blacks live an extremely different life from the whites although they are in the same country. Peter Abrahams in Tell Freedom (1954, p. 250) posits:

(...)People move towards one another only so far and then, some kind of fear seems to descend suddenly upon them and then they hesitate... many white social workers who seemed untouched by the racial disease of the land...But there had been restraint: an unspoken, unexpressed concern lest they go too far in their intimacy or lest I forget that outside these offices of the (Institute of Race Relations) the racial laws were still in force (...).

It is ironical that the whites also see the apartheid system as a barrier to their freedom also. They don't enjoy the privileges the system is supposed to give them as it alienates them to the blacks. The different races live in suspicion of each other and though some may be working together they still don't have complete trust for each other. In Blood Knot, Zachariah doesn't trust his brother when he tells him that the reason for the rise in the price for the foot salts he uses on his sore feet is because of it having better quality. In Hallo and Good - Bye the two siblings Johnnie and Hester are suspicious of each other. Johnnie suspects that his sister is up to something and that is why she has come back after being away from home for so long. Hester also suspects that her brother Johnnie knows where their father has kept the money she desperately needs. The South African blacks and whites live in suspicion of each other not trusting each other like the two siblings. Hester does not know that the father has nothing worthy to be inherited. He owns nothing apart from the clutches he uses for walking because he is crippled. Apartheid has nothing to be inherited. The system only cripples the minds of the citizens with fear and intimidation.

As stated in his introduction, Athol Fugard stages Blood Knot a play involving two brothers symbolically. Zachariah is symbolic of the black people and his younger brother Morris is symbolic of the whites. Fugard with his long time black friend Zakes Mokae form the cast. His black friend takes the part of Zachariah as he himself takes the part of Morris. They have diverse ways of doing things to show how the blacks and whites live in South Africa. Morris is the decision maker while his brother is overworked and has no say regarding the management of the money he earns. This shows that the blacks work but have no say over the resources in South Africa. Morris survives on the sweat of his brother. This is exploitation.

Fugard has a unique style of using minimal physical characters alongside others who are physically absent though very important in the story line of the play. In this play he uses only two physically present characters. Others are absent and we know them through flashbacks. The two brothers' parents are supposedly dead but their mention is highly symbolic. Their absence lays ground for the two brothers' mysterious questions about their difference in colour and the effects of the same in their lives. Zachariah wonders who of the two between him and Morris was the real child of their late mother and if they were really brothers why they were so different. Zachariah cannot comprehend why when they were young the mother favoured Morris by buying him toys while he had to do with home made ones that were not attractive.

Historically South Africa was a colony of the British and the people needed their freedom. In a monologue in Hello and Good - Bye, Johnnie states "Queen Victoria's statue is on the square and during the day pigeons sit on it..." (3) This indicates that British rule had been in place for a long time since the queen is a symbol of British power. When independence was granted, the whites hijacked it so that it became theirs leaving the blacks in a worse situation. Before then, it was known in the world that South Africa was a colony and that is why they needed their freedom. After the freedom, the black South Africans are left as internally colonized by their own brothers the white South Africans. Before the arrival of Ethel in the lives of the two brothers, there was no confusion. When she arrives, the two brothers begin to differ. In the same way, Gacheche states in her article 'South African Writing - A Brief Survey' in Gachukia $(1978$, p.196) that:

The live and let live attitude was all very well in the South Africa of 1910 to 1948 but after the ascension of the Nationalist party, no one could afford to be impartial anymore. The African had seen the vulnerability of the white man in Second World War and as getting organized in trade unions and political parties aimed at getting some of the benefits of South African affluence. In the face of this consciousness and the black menace, the white man was consolidating his position and issuing manifestos.

These manifestos were about separate development which is in reality apartheid as we also experience when 
Ethel gets into the scene though invisible. The two brothers had lived well although Morris was always a burden to his brother as he had to be fed from Zachariah's hard earned and meagre wages. Historically, the two races had lived without so many differences before the British declared independence for South Africa like it was doing for other states in Africa. This leaves us wondering whether the freedom granted to South Africa by the British was meant for only the white inhabitants or for everybody in South Africa.

Athol Fugard tries to demystify this question by bringing in minimal characters as representatives from both races to express his social vision. Some other characters are however mentioned to enhance the story line but they never appear physically although they are very important in explaining his social vision. There appears an old woman in an illusion who claims to be the two brothers' mother but they soon realize she is not. They try to chase her away but she stubbornly refuses to go. They don't succeed because each one of them tries to chase away the woman separately. However the two brothers work together, they succeed in chasing her away. Fugard's vision is that the whites and blacks work together like the two brothers. The blacks should work alongside the whites in order to succeed in overcoming apartheid.

Fugard's vision is that no race be disadvantaged by the skin colour in terms of power. The characters have been examined with regards to the relationship between power and the people in this society. In the case of South Africa as said earlier it was all about one's colour. Gergen, K. and Mary Gergen (1981,p.5) assert that the understanding of the world in an orderly way and why things happen as they do, the social psychologist relies on psychological concepts such as thought, affect, attitude, expectancy and rule. In the case of Fugard's characters, the blacks are subjected to a harsh rule by the whites as realised in Fugard's Blood Knot (1987) where the black character Zachariah is made to work at the gate where he stands the whole day and despite getting his feet sore the white boss does not change his job for another but instead ignores him.

Socially Zachariah is deprived because he is black and so nobody can listen to him despite the fact that he is suffering physically. His boss is a white man who ignores his cry because his colour gives him the power to do so. Even the language used by the boss is abusive and the reader is left to wonder why Zachariah should continue working in such conditions. The reason is that he has no option. It is either the job or he starves because he is disadvantaged by his colour. He is illiterate and has no training to give him skill to enable him to work wherever he wills. From Chris Wanjala in an article 'Fossilized Black Martyrs' edited in Eddah Gachukia and Kichamu Akivaga (1978) we learn that the blacks were victimised by the law imposing passes to restrict their movement. The blacks had to move with passes to allow them to move from place to place and also give them opportunities to get jobs.

The vision that Fugard is communicating is that there is need for change in all spheres in South Africa. That change can only be realised through the blacks and whites working for it. Morris doesn't see the need for the change in their diet. The white man does not see the reason for change because he is enjoying as we realise that Morris doesn't mind because he is not the one who does the same job at the gate of the factory. Fugard uses Morris to inform his brother that what he earns is so little that he is always struggling. Morris asserts that it is difficult to work on growth needs if one has deficiency needs and that one cannot proceed if one is struggling and spending a lot of time trying to survive. In the case of Zachariah he is trying to survive by working in a factory where no one cares about his physical and financial well being. Fugard's vision is that the blacks should realise that they are oppressed by the whites economically, socially and politically. Economic oppression is brought about by the poor wages they get from the employer.

Fugard makes use of absent characters to enhance his social vision... It all starts with Zachariah when his eyes wander through their window and he sees donkeys mating. His sexual desires are aroused and he remembers that a whole year has elapsed since he had a woman. We encounter the relationship of power and colour when the two brothers have an encounter with a pen pal as Morris again makes a decision that Zachariah should have a pen pal. The two buy a news paper and look for the pen pals. Morris has the upper hand because he can read names from a newspaper and Zachariah cannot. He chooses the name of the pen pal. The choice name is Ethel. She doesn't at any one time appear but when she comes in the story, the lives of the two brothers change. The dialogue below shows that Zacharia is not comfortable with names he hasn't encountered.

Morris: Well Zach, you ready? There are three women here. The young ladies Ethel Lange, Nellie de wet, and Betty Jones...

Zacharia: There is no Connie is there Morrie..." (22)

\subsection{Hallo and Good - Bye,}

In Hallo and Good - Bye, the playwright makes use of two characters Johnnie and his sister Hester together with absent 
and dead characters as their parents. These two also represent the two races in South Africa. The play begins with Johnnie who is alone in an empty room. This is symbolic in that Johnnie has an only sister who is also lonely but they cannot live together. The empty room is symbolic of the emptiness in the lives of the blacks in South Africa. Hester is only interested in inheritance from her father but Johnnie takes care of his ailing and crippled father. When the father dies he feels so lonely and desperate that he doesn't know what to do. Fugard makes use of flashbacks and monologues to explain why certain circumstances are the way they are. An example is the reason why Johnnie's father is a cripple. It is because of an accident he got and he had one leg amputated. He walks with the help of clutches. When he dies his son can only inherit the clutches. This is symbolic of apartheid in that it is crippling and there is nothing worthy inheriting from the system. If there is anything to be inherited from apartheid it is the crippling effect on the citizens. Johnnie is lonely and alienated to his sister Hester. When she arrives expecting a warm welcome from her brother she is shocked to realize that he is neither exited to see her nor interested in talking with her.

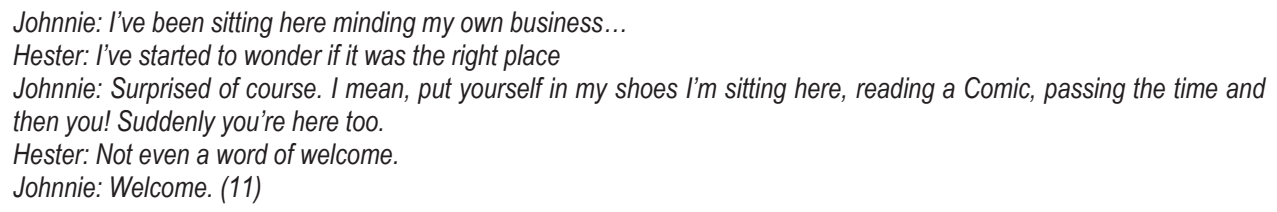

That conversation is in itself cold. "The welcome" statement is only said after Hester demanding it. Hester has been away for twelve years and her brother is not exited at all about her visit lonely as he may be. The exclamation mark in the conversation "... you!" shows unfriendliness. This is abnormal for a brother who is now an orphan and so lonely. He ought to be excited to see his sister. Fugard is showing us that the relationship between the blacks and whites in South Africa is so sore that they don't so much care what happens to the other.

The blacks have always been in South Africa and have never left because this is their home. Johnnie has been at home and has never left even when his crippled father becomes so impossibly dependent on him he doesn't desert him. Hester goes away leaving his brother who is actually younger than her with a huge responsibility of taking care of an ailing crippled father. No wonder Johnnie is not interested in her. The whites are interested with the material wealth they get from South Africa like Hester. When asked how long she would be staying in the house, Hester ignores the question and starts talking about the twelve years she has been away in a flashback. Out there she is not comfortable and she has really suffered. Like Morris in Blood Knot, Hester comes back to her brother. She is back because out there she has no money and she needs to live. She has come to see if her father has anything for her to inherit since she is his child. The whites need South Africa as much as the blacks. The only difference is that they want to take what they have not worked for. Hester has not cared for her ailing father and yet she wants to get inheritance. Johnnie has been looking after the father and is not asking for anything. He has been doing it as a duty to her father as a son.

Johnnie insists on asking his sister why she has come back.

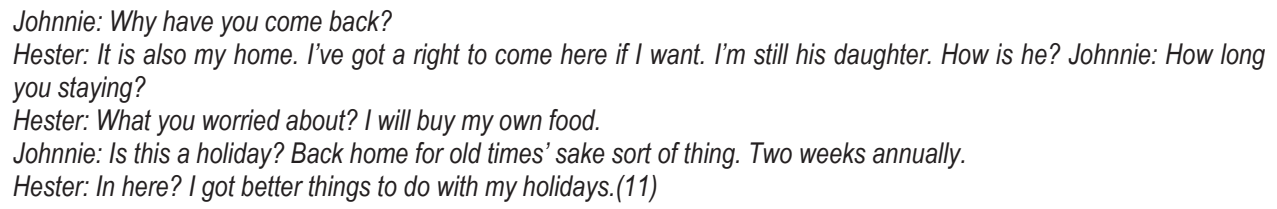

This conversation shows mistrust between Johnnie and his sister Hester which is symbolic of the mistrust in the blacks and whites for each other. Johnnie doesn't trust his sister at all and suspects she is up to something. Hester was not at all interested in her father. Her relationship with her father is sore and she doesn't care about it. All she needs from her father is her inheritance. Johnnie also tells Hester that when she left, her father had said that no one was going to speak of her again. He hated her and had said that she was not a real Afrikaner like him by nature as she had the English blood of her mother. When she asks Johnnie whether the old man still hates her and he replies in the affirmative, her response is "So what? Just remember mom didn't hate me and half of this house is hers so l'm entitled to be here."(11)It is ironical that such words can be spoken by a daughter. Johnnie pesters his sister further by also asking her whether she has actually come back for something to which she does not give a direct reply but goes round and round by replying that she hadn't stated it. She is hypocritical. She doesn't disclose her mission at first but later she makes her advance by telling Johnnie to bring her all the boxes in the house she needed to search for something. She claims that their father 
was paid hundreds of pounds for compensation after the accident that crippled him and it was hidden somewhere and that is why she needed to ransack all the boxes in the house. Through Hester the theme of greed is explored and through the father racism is expressed by the fact that he hates his daughter and adores the son who he claims to have inherited his Afrikaner blood.It is then that Johnnie realizes and asks the sister "So that's it? That's why you've come back!"(25) There is racism in South Africa and through Hester, it is evident that one race is only interested in exploiting the other. Hester goes further than that and asks her brother what would have happened to her half share if the father had died in her absence. Johnnie urges her not to mention their father's death but she doesn't care saying that "...I'm still alive, you see. Alive. He is passing away but I'm still alive. And I'm his daughter. So half of that compensation is mine."(26) The search for the treasure begins and goes on for a long time but finally there is nothing to be inherited showing the futility of the regime.

In The Island Fugard makes use of two characters Winston and John who are locked in a cell which is a small clumsy room in Robben Island. The presence of sand in the play maybe mistaken to be an additive to the description of the setting given the title of the play is "The Island". A closer look reveals that the imagery of the sand is fundamental to the understanding of the text. The sane represents various meanings at multiple levels. Fugard has creatively employed the imagery of the sand to portray the herculean task blacks are up against in their bid to stem out apartheid. This is best illustrated by the following lines:

Each in turn fills a wheelbarrow and with great effort pushes it to where the other man is digging, and empties it. As a result, the piles of sand never diminish. Their labor is interminable. The only sounds are the grunts as they dig, the squeals of the wheel-barrows as they circle the cell, and the hum of Hodoshe, the green carrion fly (page47)

This repetitive exercise leads the prisoners to a senseless state of hopelessness, despair and exhaustion. By depicting the labour as never ending, Fugard has made an attempt to vivify the tiresome and gruel some nature of apartheid. It is actually impossible for the prisoners to progress in shifting the sand and filling the holes since the task is cyclic. This scene demonstrates what prisoners experienced in apartheid jails. The struggle to make progress against the unending mounds of sand best illustrates a struggle to overcome the oppressive apartheid policy by blacks in South Africa. The unending labour has been used by the playwright to exemplify the hardships blacks were subjected to and how they endlessly worked to overcome their plight. Besides, the apartheid laws as applied by the authorities deprived blacks of their basic human right; a right to freedom of movement and interaction. Fugard has captured this by taking us to prison where Winston and John have been confined. By making them dig and move the sand, these men have been denied of the luxuries and pleasures other free people enjoy. These sentiments are echoed by Winston who tells John that he is going to enjoy beer and women once he is freed.

Fugard uses the individual grains to illustrate the separateness that defines the apartheid system. At the same time, Fugard uses sand's different colours to represent South Africa's different races. The separateness of the sand is also symbolic of the systematic break of the prisoners. The playwright seems to draw a line between the sand on which Winston and John are working on and the rocks that old Harry is working on. Old Harry seems to have reconciled himself with life in prison as his depressed mannerisms point at someone who has been turned into a stone. On the other hand, Winston is disillusioned by the news of John's imminent release. The playwright juxtaposes the impact prison life has had on old Harry and other prisoners. This is captured in the following lines:

\begin{abstract}
When you go to the quarry tomorrow, take a good look at old Harry. Look into his eyes, John. Look at his hands. They've changed him. They've turned him into stone. Watch him work with that chisel and hammer. Twenty perfect blocks of stone every day. Nobody else can do it like him. He loves stone. That is why they're nice to him. He's forgotten himself. He's forgotten everything... why he's here, where he comes from (71).
\end{abstract}

Old Harry has been made to understand that prison is his second home hence killing any hope in him of ever making it out of prison. The imagery of old Harry being 'a stone' points at extreme level of someone being broken down. The authorities have succeeded in breaking down their prisoners though differently. The portrayal of the beach may be misleading since at face value it can be thought of as a place to have fun. This could be true when the two prisoners reminiscent the time they spent at the beach. However, the ground on the beach is an unstable one. If one is walking or working on its surface there is the possibility of sinking. This shows the instability that has been brought to South Africa as a result of imposing the apartheid laws. Similarly, it is hard for blacks to make any progress in fighting apartheid as the ground on which they are standing is unstable. The labour situation of Winston and John where they are to move sand on sand exemplifies the lack of stability for blacks.

The apartheid laws have made it possible for whites to lead a stable life while blacks lead an unstable one. Hence, 
we can say that blacks are living on sand while whites are living on stable stone. Black's instability arises as a result of their confinement, oppression, torture and the repressive regime of apartheid. Fugard wants the reader to see how it is virtually impossible for blacks to make any progress while the stage has been set for white supremacy.

History has it that Nelson Mandela the first black South African president was imprisoned for twenty seven years for leading the ANC (African National Congress) a the South Africa that was demanding for equal rights with the whites. In this play, we encounter misuse of power where two inmates are ill treated. They are overworked and beaten as a mode of punishment. These two characters are also subjected to pain by an unfair guard who treats them inhumanly. The readers or the audiences watching this play are left wondering what reason there is behind the inhuman behaviour of the warden towards the prisoners.

The only possible answer is that the white man does not view the blacks as an equal human being who has human rights like his. The two men are imprisoned in a jail in an island. This is symbolic of the jail where Nelson Mandela the historical hero of South Africa spent twenty seven years. The playwright introduces a play within a play making the two inmates to take different parts in Sophocles' Antigone. In this play, the position of the character is established through what they are made to do and say. There are also absent characters like the inmates' family members, Hodoshe the harsh warden and other inmates in other cells in the same jail who do not appear physically but have a great impact on the characters on stage. Both races live in mistrust and suspicion for each other. The two inmates in a prison cell in a lonely island live in fear of the white guard Hodoshe. They are subjected to physical torture and hard labour.

\subsection{Master Harold and the Boys}

In Master Harold and the Boys, the play opens in a hotel room. The playwright presents three characters that appear physically on stage but there is mention of other absent but core characters. His parents are absent characters. His father who is ailing is said to be hospitalized and his mother has gone to visit him. This father is also a cripple and uses clutches to walk. Two of the characters Sam and Willie are black and they do cleaning jobs in a hotel owned by the parents of the third character Hally. Hally is the short form for Harold. He is young and that is why he is refered to as Master Harold instead of Mister.

Master Harold and the Boys is a play about a teenage white boy caught up in the psychological problems brought to him by apartheid laws which he cannot follow as he is supposed to. The other great problem he has is about his alcoholic father whose impact in the home is negative. He is so much involved in drinking that his hands are off as far as the family affairs are concerned. The black servants, Willie and Sam know Hally's mother as their employer at the Jubilee Residential House and later at the Tearoom because most of the times Hally's father is too drunk to even know what goes on in the place of work. The two black servants are an integral part of Hally's childhood and they are his close friends. Hally shares the education he gets from school and also from text books. Sam embraces the knowledge as he also gives Hally important knowledge about a healthy relationship with other despite the obstacles of the apartheid regime. Sam replaces Hally' father in the issues of the lessons a child should receive from a father as he grows up. He therefore emerges as a good surrogate father to Hally despite the racial segregated environment and the distraction from an alcoholic father.

As Fugard writes, Apartheid policy is in place in South African and so the play addresses the issues in the context of that regime. The playwright presents us with his social vision. The title of the play shows the racial hierarchy as a characteristic of South Africa during the apartheid.From the title, we realise that 'Master' is used to refer to whites and 'boys' is meant to refers to blacks. Through the characters in the play, Fugard presents his social vision as one of racial reconciliation, and harmonious co-existence. This has been missing due to the dehumanising nature of the apartheid policy. Sam and Willie are adults but they are referred to as boys because they are black and servants. That shows that the position of the blacks in South Africa is inferior to that of the whites who are superior because of their skin colour.

The three characters are friendly but at some point Hally realizes that his position is different from the other two because he is white. He tells Sam that his father has always told him to keep his distance with the black workers who are referred to as boys. He then says that he is now aware that he ought to have done it earlier and that it is overdue. There is a dancing competition and cripples are said to spoil the dance floor with their clutches. This is also symbolic. The cripples symbolize the whites. They are the masters but they are cripples. They depend on the blacks to do difficult tasks. Hally's father gets himself drunk and he can't walk. Sam has to carry him on his back and then clean him up because he has messed in his trousers. Hally himself couldn't fly a kite on his own. He always depended on Sam. 
Hally: Me and you.

Sam: What is strange about it?

Hally: Little white boy with short trousers and a black old enough to be his father flying a kite. It is not every day you see that.

Sam: But why strange? Because the one is white and the other is black? (31).

Hally admits that he can never fly a kite alone and that there is no chance of his succeeding without it being strange. This statement is loaded with information that on one hand it is strange that if there is going to be any success in flying a kite Sam must be there and he is a black. On the other hand it is true that Hally needs a grown up to help him fly a kite and it can never be his father because although he is a grown up, he is a cripple. A cripple can only distract the kite from flying. The playwright is suggesting here that though Sam is black and therefore supposedly inferior due his skin colour, there are things the white youth cannot do on his own despite the assumed superiority of his skin colour.

Despite having the ability to make Hally's kite fly, Sam's position is still below that one of Hally who is a child and cannot fly a kite himself. All this is because of the skin colour. With regards to this inferiority of the blacks, Marger (1999) in discussing systems of stratification states that in closed societies, mobility is uncommon as political and cultural norms and values dictate against it. He continues to state that people are assigned a status at birth as in the state of caste systems. He asserts that in the case of slavery in America, there was a system that operated as a paternalistic domination resembling a parent - child relationship between master and slave. In the case of Fugard's characters Sam's lower position is due to his colour.

The play is heavily influenced by Fugard's childhood. In a way, the play allows him to reconcile with his past, especially family ties. The relationship between Fugard and his father is central to the play as it shapes and moulds the character 'Hally'. By extension, this is what we experience in this play and in Fugard's other dramas. The relationship of Hally towards his father can be described as one riddled with emotions, love hate and resentment. Through the free indirect style of narrating, the playwright allows us to enter into the mind of his characters. AS a result we get to know a character's thoughts at the same time we get a glimpse of what is taking place in their external world. The following line exemplifies this. Hally confesses. "I love him..." (58). This admittance comes in the wake of Hally expressing his desire not to see his father. Through this, fugard demonstrates that there is still a bond between father and son despite the absenteeism.

Fugard's Master Harold .... and the boys is a play with a simple setting which allows for shift of attention to the characters. The playwright from the onset projects one of his major concerns through his two main characters Sam and Hally. Their relationship between the two can be described as that of employer and employee; companion and companion; and father and son. From the telephone conversations between Hally and his mother, it emerges that Hally's father is in the hospital. Hence, Hally's father becomes an absentee father. This scenario creates a gap in a nuclear family setting. It is this gap that Sam fills. Hally as a child needs a man, a model to look up to; one who can take care of his psychological and material needs. That is why Hally and Sam's relationship assume the path of father-son. From the play Sam is seen encouraging Hally to excel in his studies a role that should be played by his biological father. Sam also plays a crucial role in soothing Hally after the telephone conversation with his mother.

\author{
Sam: [Quietly.] That sounded like a bad bump, Hally. \\ Hally: [Having a hard time controlling his emotions. He speaks carefully.] Mind your own business, Sam. \\ Sam: Sorry. I wasn't trying to interfere. Shall we carry on? Hally? [He indicates the exercise book. No response from \\ Hally.] \\ Willie: [Also trying.] tell him about when they give out the cups, Boet Sam. \\ Sam: Ja! That's another big moment. The presentation of the cups after the winners has been announced. You've got to \\ put that in (49-50).
}

From the above excerpt, it is clear that the subject of Hally's father is a sensitive one. Hally's reaction to the news of his father's return home points at some form of conflict between the two. Since Hally's father is absent from home, he finds one in Sam. Fugard presents us with a character that has to deal with the 'loss' of his father at a tender age. This loss creates a sense of desperation in Hally who in his quest to fill the gap left by his father finds solace in one of his mother'semployee.

Hally's relationship with his father can be said to be a distant one or superficial. This can be partly explained by the burden left to Hally, that of tending his father's gammy leg and two due to his father's physical condition. As a young boy Hally needs to be emotionally connected with his father. Contrary to this, his father is physically and psychologically absent from Hally's life. Hence, Hally comes to resent his father's physical weakness, absentness and negative political 
views. His father's absentness can be seen in terms of political views. Besides, as a man, Hally's father has failed to portray himself as a perfect head of the family. Sam also empahtically says that he does not recognize Hally's father as his boss because he does not pay him. The title goes to Hally's mother.

Fugard's parentage has played a big role on how he dramatizes the tensions he is writing about. Fugard is born to an Afrikaner mother and a father who is of English decent. These differences of origin to his parents have compelled Fugard to express the religious, political and racial conflicts that accompany them. For instance, the discussion between his main characters, Sam and Hally, on who should be regarded as 'a man of magnitude' demonstrate religious differences of his time. There is an evident gap between two beliefs, one, a belief of the evolution and the biblical teaching of creation. Hally cites Charles Darwin as his 'man of magnitude' since he is someone "... who benefitted all mankind" (19-20). Hally's admiration of Charles Darwin's Theory of Evolution is in stark contrast with Sam's views. Hally argues that the theory answers the question of the origin of the human race. According to Hally, the theory proves "where we come from and what it all means" (19). Sam on the other hand totally refutes Hallys claim by stating that Jesus Christ is his 'man of magnitude'. Sam postulates that the theory of Evolution contradicts the Bible's founded belief that humankind are a creation of God. Sam disqualifies Hally by saying that Hally does not have "...to believe it" (20) just it is written in a book.

The different religious opinions emerge as Sam strongly believes that Jesus Christ is 'a man of magnitude'. It is not expected of Hally to share the same views as Sam since he blankly declares that he is "an atheist" (22). This difference in opinion between Hally and Sam captures the religious tensions in the society the playwright is writing about where there was a general acceptance of the Theory of Evolution and the preference for the teachings of Jesus Christ.

\section{Gender Dynamics in Athol Fugard's Drama}

Gala (1974) observes that "Fugard can be looked at as an example of the contradictions within White South African society. As a force for social change" (100). Through Winston, the reader is able to see how the female gender is been appropriated into Athol Fugard's text in his quest to bring change to Apartheid South Africa. Winston displays an act of humiliation when John approaches him and tells him to play the role of Antigone. In order to have an Antigone alike, John provides Winston with a costume, a wig and fake breasts. The playwright creatively captures a man who is visibly humiliated and angered when John tells him that "[he's] not doing it [and that John can take] Antigone and shove it up his arse!" (Fugard, 2007). To Winston it seems like a belittlement when he is offered a woman's role. He expresses his fear that the audience will jeer and mock him but John explains: "... Yes they will laugh. But who cares about that as long as they laugh in the beginning and listen at the end..." Later on he realises himself as a victim of the same law and decides to act.

The costuming of Winston best captures the anger of blacks in South Africa against the oppressive and inhumane regime of Apartheid. Winston's protest about the costume is an emphatic demonstration of the damage the apartheid system has had on the identity of black in South Africa. Athol Fugard impresses on his audience that in spite of Winston's initial position in which he regards Antigone's role as belittling him because Antigone was a woman, he later he realises that he himself is belittled by the apartheid regime because he is a black. Towards the end he identifies with Antigone regardless of her being a Greek creation. This is because she is a human being who has been misjudged despite her colour. A wrong committed to a human being is a wrong regardless of whom it is committed to.

Athol Fugard captures the Apartheid system in its oppressive form. In his quest to castigate the South African law, he uses a female character, Antigone, to expresses the disharmony that the law has brought about. Through Antigone, he succeeds in satirising the Apartheid law. The playwright's heroine Antigone breaks the law in an act that even King Creon could have been engaged in; burying her brother Polynices. In this act of defiance the playwright demonstrates the futility of the oppressive Apartheid law. Antigone demonstrates that the fighting spirit that cannot be kept under by laws made by man. In Antigone, Athol Fugard establishes the conquering spirit of a woman. Thus, the female gender is able to rise above the laws prejudices to the extent of seeing her brothers' bodies as equal in spite of them being on either end of the war. If one needs burial, the other also needs it. In Antigone, Athol Fugard is able to elevate to an equal position to that of males the female gender.

By bringing in this play within the main play, The Island, Fugard is communicating to the audience that injustice is a vice found with those in power. John is taking the role of King Creon who represents the state. The state has the law on its side and so anyone who goes against King Creon goes against the law and has to face the consequences. This is congruent to the apartheid law which is unjust but still is 'the law' and nobody questions the law. Antigone pleads guilty and states before every one and says loudly before them all: Gods of our fathers! My land! My home...: I go now to my living death, because I honoured those things to which honour belongs. (77) She declares that the fact that she has 
buried her brother is an act of honour to the death irrespective of the circumstances surrounding the death. An allusion to the fact that in South Africa the blacks deserve to be treated like human beings and not as inhumanly as they are treated as if their black colour is not human.

Athol Fugard speaks for those who are socially and economically deprived and do not have the power to voice their grievances. In this play we see the misuse of law and powers by those who are in power on their subjects. Antigone states: "I buried my brother. That is an honourable thing, Creon. All these people in your state would say so too, if fear of you and another law did not force them into silence. " (76) The playwright through Antigone boldly states that it is commonsense to know the right things to do but people are blinded by the apartheid laws and so they are silent not because they are ignorant but because they fear to challenge the law.

In the play, The Island, through the heroine of the play 'Antigone' that the author opens the eyes of his audience to see the reality of the misuse of power as a theme in this play. 'Antigone' the character is a sister of two brothers who die in battle though on different sides and she buries the body of one because it has been left unburied. This concurs with Wertheim (2000) who states: "the audience however begins to realise that Athol Fugard has chosen the Antigone story because it is a legend that embodies the history of protest and Winston's life is thus a history and legend in one."(93)The character Winston therefore stands for those who represent historical legends in South Africa.

Antigone is depicted as brave. She does not fear even death and tells the king "Your threat is nothing to me, Creon. But if I had let my mother's son, a son of the land, lie there as food for the Carrion fly, Hodoshe, my soul would never have known peace."(76) She says the words with such finality that it is hard to believe that she is talking to a person who holds her life like King Creon. She has no fear because she stands for truth and says she feels no shame that she is sentenced for life imprisonment in the island. She is brave as she states that she goes to imprisonment without resentment because she is not guilty.

In bringing in Antigone as a play within the main play The Island, Athol Fugard not only consolidates the position of women in the society but also projects his vision that the blacks should realise their position and they should like Antigone be brave enough to take their position. Thus, Antigone offers the playwright a voice to state that Athol Fugard's vision in that a person who is sentenced unfairly by unfair laws remains innocent although he may suffer. Like Polynices, they are viewed as traitors and they deserve no honour. Brave people like Antigone should arise and stand for the truth even though it means going to prison.

Athol Fugard uses a female character to posit that it is only right to point out the inequities in the society. Through dramatisation, he urges his audience in South Africa not to act not according to laws of apartheid made by man but according to humane laws. Winston states that "even as there are laws made by man, there are also laws made by God" (76). Athol Fugard in using this Biblical allusion stresses the need of love for human kind regardless of colour. Antigone's argument is that when Polynices died in battle he was just a dead body which needed a burial like any other. Through the actions of Antigone, the audience learns that they need to look at each other as human beings. It does not matter what colour one is as long as one is a human being.

Athol Fugard uses the technique of play-within-a-play to ritualise political martyrs in honour of those who have been imprisoned, those who share Antigone's fate. Beside, this enactment has enabled Athol Fugard to vividly dramatise femininity and its power to resist segregation and subjugation. The end of the play elevates and emblematises femininity as it joins hands with masculinity as depicted by John and Winston in the bold declaration: "Brothers and Sisters of the Land! I go now on my last journey ... condemned alive to solitary death...I go now to my living death, because I honoured those things to which honour belongs" (TI 77).

Athol Fugard underscores the centrality of gender in Blood Knot. This emerges clearly in the way he creates, introduces and uses his female characters, most of whom who are absent, to the realisation of the general aesthetics of the play. Even though from the onset the whole idea looks vulgar, Athol Fugard uses his female characters to the realisation of his objective. The female voice offers the playwright an alternative channel of illuminating the vices in the South African society. At first he projects his female characters in Blood Knot as objects of pleasure. It is ridiculous that the mere act of witnessing donkeys mating, Zachariah's sexual urge is aroused. It dawns on Zachariah that it is a year since he enjoyed the company of a woman. "Hey! I remember now! By hell! About Minnie. How did I forget... it was a woman! That is what we had when we went out at night woman!"(11) This also coincides with the period Morris has stayed with him. Athol Fugard uses Zachariah's instant arousal to comment on how blacks in South Africa have been imprisoned by whites and the need for them to enjoy freedom like their white brothers.

The desire to have a woman takes centre stage despite Morris' attempts to derail the thoughts of Zachariah: "You are not going to make me forget. I won't, I'm not going to. We had woman, I tell you. Woman, Woman! Woman!" (12) The use of the short sentences, exclamation marks and the full stop show immediacy. The use of a female character enables the playwright to draw the reader's attention on the urgency and need to address the plight of black South Africans. 
Zachariah's stubbornness and nostalgic feelings of his pleasurable time with Minnie points at the need for freedom. The introduction of Morris to Zachariah's life is a rude interference to his social life and by extension, the interference of whites on black people's lives. The playwright captures this when he observes: and it was you standing there, and I said something... come in, I said a whole year of spending tonight talking, talking. I am sick of talking. I am sick of this room. (12). Zachariah's desire leads him to speak with a finality that he no longer needs to be enclosed but be a free person before the arrival of the white man.

Filled with nothing but the nostalgia of freedom Zachariah reminisces, "The first one. My very first one... her name was Connie...Connie Ferreira... it was the year when you [was] away."(16). However much Morris wants to change the subject of discussion, Zachariah is adamant that he wants back his time with his women, his time when he enjoyed freedom before the intrusion of the white. Athol Fugard uses the female gender to allude to the freedom that existed before the coming of the white man. Before the whites arrived in South Africa, the blacks had their own life which was enjoyable. The arrival of the white man reduced the black man to one who could not do anything for himself. Zachariah needs a woman but it is the brother who should decide who and when.

However, we are able to see how through the desire to have a woman religion has been used to suppress the African's feelings and desires. Morris uses the bible to make Zachariah feel guilty and so be contented in doing without a woman. Morris reads: And Asa begot Jasphat, and Josaphat begot Joram..." Morris is trying to discourage Zachariah from talking about his urge for a woman using the bible to show him that sex is only permissible in the biblical way where people marry and get children. Athol Fugard has not shied away from demonising his female characters as a reawakening in his male characters and his audience in general. The playwright Athol Fugard demonises Ethel in the brothers' adventure. The pen pal, a white as it emerges, turns out to be a torment to Morris and Zachariah when they realise the skin colour of their pen pal lady. The playwright does not only use her to ostracise the brothers but also to depict the rift between blacks and whites in South Africa.

The playwright also dramatises the contradictions prevalent in the South African society through Ethel. The bothers, Zachariah and Morris, share a room and more importantly a mother but they are worlds apart. It emerges that Zachariah cannot read and write. This is especially since it is Morris who reads out the instructions on the foot salts. Similarly, it is Morris who reads and writes the letters to and from Ethel. Her deliberate intrusion into the lives of the brothers enables Zachariah to "... probe his blackness, first to cringe from it, debase himself before it, then to glory and triumph in it" (Gala 1974, 102). This is evident in the climax of the text where the Morris and Zachariah act out in line with their skin colour. As (Gala 1974) observes, this results in "...subservience, cringing humility, then a creeping apprehension, a growing awareness, fear, terror, the falling darkness while Zachariah - and South Africa - stand in wail" (102).

Athol Fugard's quest is that liberation can only be possible when the blacks realise their position, hate it and then fight against it. Zachariah tells his brother in answer to "the whole, rotten, stinking lot is all because I am black. Yes. That explains it, clearly. [Which is something.] I mean when a man can see 'why quite clearly, it's something. Think of those who can't."(62) This is what Athol Fugard does. He opens the eyes of the audience through this realisation. It is then that Zachariah states:

I take it. I take them all. Black days, black ways, black things.

They're me. I am happy... I am on my side; they're on [theirs]...

I will be what I am. They can be what they like. I don't care. (63)

Athol Fugard uses the sex image not because he is vulgar but because he wants to show the level of deprivation for the black man. He juxtaposes the black man's deprivation of sex which is a need to the freedom the donkeys have as they can mate anytime anywhere as Zachariah had watched them do through the window. Morris reads the bible to his brother and then mends his torn coat telling him that he is helping him. "I am helping you, aren't I Zach? I want to believe that. You see... there [was] all those years, when I was away." The white man tries to justify his presence in South Africa and misuses religion to show that he is helping the black brother to move on. When Zachariah asks Morris why he came and why he stayed, Morris answers that: "we are brothers, remember" (19).

The racial dilemma intensifies when Ethel sends another letter stating her interests to visit Zacharia. It dawn on Zachariah that his skin colour will not allow him to meet Ethel. This racial barrier makes Zachariah give up his right to interaction to his brother Morris saying, "She is yours. I'm giving her to you....look. I can't use her... but why throw away a good pen pal if someone else can do it?" The prevailing situation is as bad as that. Zachariah has to give up his pen pal. Morris has to meet Ethel and not Zachariah because there is racial segregation. There power in the white skin color as opposed to the black colour. 
The conversation drifts from Ethel to their mother when Morris tells his brother that he's playing with fire in trying to reply Ethel's letter and to retain hers and also keep the photograph. Zachariah laments that he never had much to play with reminding him that he really wanted to but their mother only gave him her old cotton reels to play with. The mother favoured Morris and gave him toys because he was younger The white man has always had his way in south Africa as opposed to the black man. In a flashback Zachariah remembers one of their mother's childhood songs in which she elevates light skinned people over their black compatriots. Zachariah bemoans the fact that their mother favoured Morris when she openly sung that, "... you'll get to the top.'(48) The mother's voice elevates the light skinned son. This tells us that the mother put the light skinned child ahead though he was younger. Athol Fugard satirises the mother to demonstrate outright bias to one of her children. Zachariah bemoans the fact that Morris always got the best at his expense: But I never had much to play with... Ja. Like that top, Morrie...She gave me her old cotton -reels to play with, but it wasn't the same. I wanted a top. (47)

Athol Fugard still engages the mother metaphor to demonstrate that the black man is no longer naive in asking the Apartheid system. The playwright delves into the apartheid regime by asking: "...Whose mother were you really? At the bottom of your heart, where your blood is red with pain, tell whom did you really love?... you see he has been such a burden as a brother" (81). The playwright voices his concerns on the outright segregation to brothers. The blacks and the whites are brothers as represented by the two brothers so they need to know why one should be elevated over the other. Before they can enjoy the brother hood, certain things must rectify. They must find themselves first.

The appearance and attempted chase of the old woman who claims to be their mother reflects on the fact that the two brothers need to join hands in order to do away with apartheid. Morris and Zachariah each try to chase her away but she stubbornly refuses to go. However, when the two brothers work together, they succeed in chasing her away. The playwright brings into the mind of his South African audience that whites and blacks need to work together. The same sentiments are echoed by Jameson in his text The Political Unconscious (1981). In borrowing Freud's idea of the repressed unconscious he discovers a Political unconscious which amounts to the repressed conditions of exploitation and oppression.

According to Kabira and Masheti (who are referring to women, although the extract stands for all), the use of names or labels "often bestow status, or demean, patronise or generally shed light on inherent attitudes towards the person or persons addressed" (1997: 20). Athol Fugard uses these names or labels skilfully throughout his work to convey these 'inherent attitudes' and to show the audience how names are used in "...shaping attitudes towards characters in a text" (1997: 17). By naming a person or group on the basis of skin-colour, one forces them to inhabit a specific territory (in these cases economic, social, class), the boundaries of which are immovable until the emphasis of colour is removed.

Naming and classifying language is primarily directed at Zachariah as the "dark-skinned" brother (Fugard; 2000: 52) in Blood Knot. In Scene One he describes the rape mentioned previously as having been a result of being called a "black hotnot" by "the bitch" (Fugard; 2000: 63) yet infers that this was mere pretext because she had "tits like fruit" (Fugard; 2000: 63). After Zach is treated badly at work (he is told "Go to the gate or go to hell...Boy", Fugard; 2000: 74), he and Morris discuss prejudice, injustice and inhumanity. However, when he finds out that his pen pal is in fact a white woman, he happily proclaims the heart-breaking: "And this white woman has written to me, a hot-not, a swartgat. This woman thinks I'm a white man. That I like!" (Fugard; 2000: 77), proving that entrenched government propaganda not only persuaded white people to view non-whites as inferior, but that many non-whites came to believe it themselves. The introduction of Ethel into Morris and Zach's lives causes several moral dilemmas, their potential consequences comprehended more fully by Morris than by Zach. This leads into their role play, as Morris acts as the white man for which he is able to pass by wearing the clothes they have bought with their savings. Not only are the brothers able to vent their frustrations with each other as members of different races, but throughout this role play the brothers are also able to express their feelings about their mother, who "made life unbearable", calling her "Kaffermeid", "Ou hoer", "Luisgat" and "Swartgat" (Fugard; 2000: 118).

The English Queen's statue is used by Athol Fugard to declare that South Africa historically was a British protectorate. In a monologue in Hello and Good - Bye, Johnnie states "Queen Victoria's statue is on the square and during the day pigeons sit on it..." (3) This indicates the presence of British rule and the queen's statue is its symbol of power. When independence was granted, the whites hijacked it so that it became theirs leaving the blacks in a worse situation. Before then, it was known in the world that South Africa was a colony and that is why they needed their freedom. After the freedom, the black South Africans are left as internally colonised by their own brothers the white South Africans. In the same way, Gacheche states in her article 'South African Writing - A Brief Survey' in Gachukia (1978, p.196) that: 
The live and let live attitude was all very well in the South Africa of 1910 to 1948 but after the ascension of the Nationalist party, no one could afford to be impartial anymore. The African had seen the vulnerability of the white man in Second World War and as getting organised in trade unions and political parties aimed at getting some of the benefits of South African affluence. In the face of this consciousness and the black menace, the white man was consolidating his position and issuing manifestos.

These manifestos were about separate development which is in reality apartheid as we also experience when Ethel gets into the scene though invisible. The two brothers had lived well although Morris was always a burden to his brother as he had to be fed from Zachariah's hard earned and meagre wages. Historically, the two races had lived without so many differences before the British declared independence for South Africa like it was doing for other states in Africa. This leaves us wondering whether the freedom granted to South Africa by the British was meant for only the white inhabitants or for everybody in South Africa.

South Africa is a mother to both blacks and whites. It has given birth to them and there are no means of separating them. Athol Fugard in Blood Knot observes, "No. You see we are tied together, Zachariah. It's what they call blood knot... the bond between brothers."(97) Their kinship is sealed by a knot in blood which is hard to separate or untie. The playwright through the title is suggesting that the races in South Africa cannot be separated. South Africa is like a mother to them and so none of them should leave. Brothers should reconcile not separate and so the blacks and whites in South Africa should come together and learn to live together as brothers. They should also share the resources of their motherland like brothers who share a mother.

In Blood knot, Ethel, Zachariah's real mother and a fake mother, his girlfriends like Connie and Minnie are invisible but they shape the story line. The real mother is symbolic of South Africa. She had two children. One is black and the other one is white. That tells us that South Africa belongs to two races; the blacks symbolised by Zachariah and the whites symbolised by Morris. The fake mother symbolises apartheid and when chased away by one son she becomes stubborn. She only disappears when the two sons join hands and chase her away. Ethel is a pen-pal and she is symbolic of apartheid. Morris tries to make his brother Zachariah take a pen pal to replace his desire for a woman. It can't work. Apartheid cannot replace the real freedom the blacks need. Minnie and Connie are real. Zachariah remembers the enjoyment he had when Minnie visited him and they went out together. He felt satisfied that he had a real woman. The blacks need real freedom not the imaginary independence in form of Apartheid where they suffer in their own country.

The following line capture the playwright's intention in the text, Blood Knot. Morris says: No she's not coming; never prepare you for gone. Ethel's gone and got engaged to get married to Lucky man Staffe. Ethel is gone. She is symbolic of apartheid. Apartheid is gone. So the two brothers now have to start a fresh. They have to go back to where they were before the pen-pal business. The blacks and whites have to go back to the time before the introduction of apartheid.

It is through Hester and John the two siblings in Hello and Goodbye that Athol Fugard tells his the audience the vision he has for South Africa. Hester sees their parents' marriage certificate and remembers her dead mother in a flashback and says that the biggest mistake her Mommie made was getting married to their dad. When Johnnie argues that their dad never beat their Mommie Hester stated that he did it in other ways. This means that the father may not have beaten her physically but may have mistreated her leading to psychological torture and social alienation. This explains why later in life Hester never wanted to get tied down to one man through marriage.

Hester tells her brother that she saw the look in their mother who fell in her grave looking tired and frightened. The tired and frightened look must be a result of the psychological problems that she had encountered in her life. Her social, life must have been a disturbed one. Hester states: "She worked harder than anybody I ever seen in my life, because she was frightened. Hester was frightened by her mother's look. Mother said I frightened her. Our frights frightened her. She died frightened of being dead." (40) It is through Hester that Athol Fugard states what the disadvantaged person should do. "Mommie should have taken what she wanted and then kicked him out." (4) Johnnie persuades her to reason about the children but she says that children should not tie anyone and discloses that she had aborted hers. Johnnie goes religious and wants Hester to feel guilty but she insists on freedom. "So I'm here because she was a fool. We are all somebody else's mistake... The whole damned thing is a mistake. The sooner they blow it up with their atom bombs the better", (42) the playwright states that the oppressed black man would free himself regardless of the cost.

The playwright's sentiments are qualified by Roberts (1999, p.1979) Sigmund Freud who claims that behavior is caused by hidden and unconscious motives. Hester and Johnnie are products of a marriage that was miserable. The people of South Africa are a product of the Athol Fugard is trying to show the mistakes of apartheid. The products of it are misery for the people of South Africa. At the end, Hester leaves and goes back to her life. She needs no more inheritance. Johnnie is left alone. He tries the father's crutches but finally says he needs a resurrection. South Africans 
need a rebirth so that they can realise themselves. It is through Hester that Athol Fugard communicates his vision against the Apartheid regime using the image of clutches.

Athol Fugard uses a female voice to project the white person's detestation of South Africa. The playwright observes, "It is hello and good - bye" (11). Athol Fugard informs us that the whites only came to visit. Hester had left the home but she has now arrived. She has come but she is leaving. The white man came to South Africa in the seventeenth century but does not love South Africa. They like Hester they are on a mission. The mission is materialistic based and once accomplished, Hester will leave. She does not care about her father's sickness. She has come for her inheritance. Johnnie can continue taking care of their father but it is money she is interested in.

Hester comes home to prick the conscience of her brother Johnnie. Johnnie carries his sins in the form of his crutches and when Hester asks him why he says that their father is bedridden and doesn't need them. Hester gets mad at him and tells him "Then take them. Be cripple!" (45) Athol Fugard is actually showing that as long as the blacks follow the status quo they shall be cripples but if they can free themselves they can bring change. Hester bears the playwright's message of change when she implores her brother to join him saying, "Hang on, Johnnie. Listen - Pack up and come with me ...Anything! Anything is better than this, Boetie. Get a job, a girl, have some good times." (50) The brother replies "Suppose just suppose there are ghosts, and he did come back to haunt, and I was gone! I will stay, just in case, I'll wait." (50) This conversation ends when Hester leaves and Johnnie is left holding the crutches. Johnnie inherits them and assumes his father's life. Athol Fugard posits that blacks will have to take their position like Hester and hence the title because at the end she says goodbye to apartheid when she realises there is nothing but crutches and cripple hood to be gotten from that regime.

Athol Fugard in using Hester to look like an ungrateful child who wants her father dead so that she can get her inheritance is two edged. On one hand Hester is sending a message that the whites as well as blacks are tired of the old system of apartheid. Apartheid should by now be a thing of the past. The system is old and unworthy. The father is sickly, groaning and very boring. According to Hester, her father's sickness is overdue and he should be dead to set everyone free. If he were dead as should be, Hester could get her share of inheritance and John would be free to do his own business independent from his father and free from nursing a person who will probably never recover.

On the other hand Hester is also sending a message that she wants her own life separate from her brother. The reason she left home was that she was bored and none understood her. She says "None of you know me..."I will say it again "None of you know me". The repetition of" none of you know me" is meant to emphasise that Hester although a member of the family is very different from what anyone would imagine. This is a member of the family who is selfish and greedy. Hester cares only about herself. She is not interested in how others feel or get affected by her behavior. In the situation of South Africa of that time, such a character could represent the whites who are selfish and do not care about what the blacks go through. They didn't care about the political, social, economical problems the blacks went through. Their interest was only on what they got in terms of material wealth from South Africa. Hester insists that when the father dies, half of what he owns goes to her. She is however not interested in his health. The white man is not interested in the well being of South Africa as a nation but rather on the material products.

After a heated argument, Hester tells her brother that finally when their father dies, they should love each other and live happily thereafter. She is however saying it sarcastically because she immediately says:

There's man. And I'm a woman. It is as simple as simple as that. You want a sin well there is one I Hoer. I have hoered all the brothers in this word into one thing. Man. That's how I live and that's why I don't care. And now I am here waiting. Because when he wakes up I am going in there to tell him I want it. My share.

These words from Hester are telling the reality about the blacks and whites in South Africa. Athol Fugard uses her voice to state the truth that the whites have no concern about the blacks. Hester in her own voice states that she has been a whore and that proves that she is immoral. She is not ashamed to say these shameful words to her brother. She tells him she has been prostituting with all men regardless of whom they are provided they are men and she is a woman. This is immorality that the playwright equates to what the whites have been doing all over the world taking other people's land and making themselves their rulers not caring about their feelings. Hester declares what kind of a person she is to clear doubts to her brother about why she doesn't care about her father's health. She has lived a life of wickedness so taking inheritance from a father she hates is not a new evil to her and so she doesn't care.

Johnnie is so concerned about morals and tells her not to do such thing to her father but she doesn't care. Athol Fugard is telling the audience through Hester that the whites don't care about how immoral it is to treat the blacks the way they do. The regime cares about what they gain from South Africa and not the way through which they get the material. It is then that Johnnie asks his sister to get her share to which she promises she would. They then agree that Johnnie 
would go to his father's bedroom and bring all the boxes to Hester so that she can search them. It is a tedious job but Johnnie does it because he doesn't want Hester to go inside and then discover that the father is not in the room.

Johnnie does not trust his sister. This is the reason why he does not disclose to her that their father is dead and buried. The blacks don't trust the whites. They live together and yet they don't know each other well. Hester and John are siblings but they don't know each other. Hester had earlier said it. This is because the sister is a hypocrite. She is hiding something from her brother. She has always been like that. The whites are hypocritical and therefore are not known well to the blacks though they share South Africa. The reason could only be one. The whites want to take advantage of the blacks.

Hester in her quest to get her share inheritance denounces her father. This act not only dehumanises her father but also herself. Hester also is not so much interested in him. She has only come to get her share of inheritance. She is so desperate. She is poor and needs money to maintain herself. She even declares her hatred for her father and accuses him of invoking their mother's death because of mistreating her. The impatience of white to the South African society is manifest when Hester does not heed to her brother's idea of growing seeds. If the seeds can be given the right treatment, they can grow. Hester is not interested in growing seeds that can take months to grow. Johnnie says, "But think of it. Ripe watermelons" (36). Hester would succeed if she heeded Johnnie's words. For Hester, that would take a long time. She doesn't have that time. The white man wanted his freedom from the British so that he could run his own affairs in South Africa without interference from the colonial master.

Athol Fugard's wish is that the two siblings should live in peace and each one of them should get a share of inheritance from the father but ironically there is nothing to be inherited. The playwright gives his two characters nothing to inherit. After the big search from all the boxes, the two siblings get nothing worthy apart from clutches. Johnnie takes the clutches and tries them but her sister stops him. Hester is human for the first time since she came. She discourages her brother from faking cripple hood. Athol Fugard uses Hester to shout to the blacks not to ape the whites in any way but to be themselves. She encourages her brother to try any kind of work for his livelihood but to forget the clutches. Athol Fugard's vision is that the blacks should not segregate the whites once they are in power like the latter have been doing.

Hester and her brother struggle as Wertheim $(2000,47)$ states: "There is something there in that house over which Johnnie and Hester will struggle antagonistically like siblings over a birthright." Athol Fugard is foreshadowing the struggle that will be there between the blacks and whites. The blacks will be trying to get back their position as the whites resist maintaining the status quo. The vision here is that the blacks should realise their position in South Africa and fight for it. Hester misuses her position of birth by trying to force Johnnie to give her what her father left. Finally when Hester discovers there is nothing she makes her exit. Hester has a personal problem that is likely to spill to others making it a social one. As expressed by Lauer (1998, P.4), a personal problem is one whose causes and solutions lie within the individual and the individual's immediate environment. A social problem is on the other hand one whose causes and solutions lie outside the individual and the immediate environment. The problem of apartheid and racial segregation begins with individuals. It begins with the white man looking down upon the black man. This is later spilled to the whole society which becomes stratified in terms of colour as the white man assumes superiority over the black man.

Master Harold and the Boys is a play about a teenage white boy caught up in the psychological problems brought to him by apartheid laws which he cannot follow as he is supposed to. He is forced to put up with the rigours of adult life at a tender age. The situation is worsened by the fact that he is surrounded by adults whose actions and behavior he has to put up with. At his age, his mother informs him that he is a master. "My mother is right. She is always warning me about allowing you to get too familiar" (53). Masters Harold realises he is the master when his parents are absent. He is the master while Sam and Willy are mere black servants. This form of negative indoctrination from his parents is what we experience later in the play when he tells Sam, "You are only a servant in here and don't forget it. And as far as my father is concerned, all you need to remember is that he is your boss." (53) These words from a white boy mean a lot. Colour in South Africa is what matters. Sam had forgotten himself because he had gotten too used to being with Hally. Athol Fugard uses a dialogue between the two to remind them their position so that they can start realising themselves from there. Besides arousing a consciousness in Sam and Willy, the playwright seeks to have a reawakening in his white audience that it is immoral for a white boy to treat elderly black males like thrash. In essence, Hally needs a liberation from himself.

Hally is imprisoned by the kind of life he is exposed to. At the Jubilee House, most of the time he is running away from the pressures of his family. Either his parents fighting of his mother quarrelling with one of her staff. This in turn sends him to the servants' room which he thinks is a safe haven but then lands him in more life intriguing episodes than the ones he is avoiding. His escape to the servants' quarters makes aware of the escapades that take place there, he gets to know the level of prostitution in the premises. Through the eyes of a young boy Athol Fugard tells of a trapped white South African that is seeking an exit from its problems but cannot find one. 


\title{
Athol Fugard observes:
}

\begin{abstract}
I think I spent more time in there with you chaps than anywhere else in that dump... Somebody was always complaining about the food, or my mother was having a fight with Micky Nas because she'd caught her with a petty officer in her room. Maud Meiring was another one" (26).
\end{abstract}

It is evident that Hally was always running away from the many pressures and pleasures of adulthood that he was exposed to as a child. He says, "...God, the flotsam and jetsam that life washed up on our shores! No joking, if it wasn't for your room, I would have been the first certified ten-year-old in medical history..." (25) Through the trapped and filthy body of Hally, the playwright has succeeded in creating a very powerful image of pollution. Hence, there is need for purification and cleansing. Hally and the white South African audience need a bodily and spiritual cleansing in order for them to be free.

Athol Fugard once more engaged sex images to put across his point. The playwright makes reference to 'smells coming from the lavatory'. Hally also acknowledges that their Jubilee House is a place replete with sexual activities. His observation saliently denotes a tendency toward purification and self emancipation. This is especially so when Hally recalls how he caught Sam with Cynthia in bed. The sex image of purification if further elevated with the decoration of Sam's room with a poster of a model Rita Hayworth, one that always made Hally "...hot and bothered..." (26) Whenever he looked at it. Thus, Athol Fugard succeeds in impressing upon his audience that they need ritualistic cleansing.

We can only remain healthy after eliminating toxics from our bodies. Athol Fugard uses prostitution to demonstrate social decadence. Besides, the physical act of sex between the sailors, soldiers and prostitutes at Jubilee House point at a biological act of attaining psychological health. Prostitution and sex as used by the playwright help his characters in expunging self-guilt. Thus, Hally and other whites are engaged in this symbolic purification from negatively charged ideas of segregation and oppression. However, in seeking to be true to life, Athol Fugard aspires also to portray the dark side of life.

The playwright also makes reference to legs. Sam says, "He's got leg trouble." (10) Athol Fugard compares life to a dance. He says that one can fully be part of a dance if their legs work properly. His characters, Willy and Hilda find it hard to match the movement of their legs. Willie laments, "...That's her trouble. She can't move them quick enough...I start the record and before halfway Count Bassie is already winning. Only time we catch up with him is when gramophone runs down." (7-8) The inappropriate legs have also been employed by the playwright to comment on Willy's character. The playwright describes Willy's bed as one that has a broken leg and hence has to be supported by bricks. The want in Willy's character is seen as he seems to be unfulfilling most of the time.

Athol Fugard has endeavoured to capture the limited view of life of his white characters especially Hally. Hally interprets the dance differently. He sees the dance as a political arena "Ballroom Dancing as a Political Vision" (47). And as a way of "...the release of primitive emotions through movement..." (43). Hally's limited view of the dance demonstrates his inability and by extension that of other whites to view the world from a wider spectrum. In an article by John Kenneth Galbraith in Martin Merger' Social Inequality (1999) Galbraith argues that the social class is the most consequential form of stratification, exceeding ethnicity, gender and all others. (23) Social Class can be classified into economic class and 'lifestyle' Galbraith explains

\begin{abstract}
Social Class can be understood as groupings of people who share roughly similar incomes and wealth, similar levels of education... income and wealth, occupational prestige and educational level are closely intertwined and together create economic community... classes may be thought of as groupings in which people share not only similar occupations, incomes and level of education but also similar lifestyles... for example the upper class people generally use different patterns of speech, maintain different tastes of music, fashion and cuisine, decorate their houses differently and prefer different forms of leisure than do either middle class or lower class people (24).
\end{abstract}

Sam is teaching Willie to get the right steps with his dancing partner Hilda. Changing the partner is not the issue. The issue is learning and following the right step with the same partners. He uses satire on his friend Willie who is complaining that Hilda cannot dance well. Willie justifies himself as being a good dancer but his partners are not. There is need for every individual to come out of the self, acknowledge the weaknesses and strengths of the other if there is to be progress.

Athol Fugard uses gender to artistically capture the mistrust that permeates the lives of blacks and whites in South Africa. Willie can't trust Hilda who is his girlfriend and supposedly mothering his baby. He complains that every week he gives her money for milk but he is not sure the baby is his. "And how do I know the baby is mine? Only his hair looks like me. " (6). The blacks in South Africa are not confident on anything around them. They have been short changed for too 
long. They can no longer have trust either in their white brothers or even in themselves. Hilda does not go to practice the dance with Willie and so he doesn't trust her anymore. The blacks feel alienated to the whites. They can't trust them.

In Master Harold and the Boys Athol Fugard in using the character Willie, trying to make Hilda his partner by beating her he is opposing apartheid. Apartheid as a system ill treats the blacks forcing them to work to build the nation through underpaying and overworking them. Instead of joining him in practicing for the dancing competition, she boycotts the whole thing messing up Willie's plans. Sam tries to explain the reasons to Willie but he justifies himself. Sam conclusively tells him: "You hit her too much. One day she's going to leave you for good" (7) He also reminds him that he had the same problem with Eunice another absent female character to which he replies that she never got the dancing steps right even in the waltz. This argument is endless showing that in South Africa, the blame game is futile and can never yield any positive results for the different races.

The playwright suggests reconciliation between the two races as the way forward when Sam encourages Willie to apologise to Hilda if he hopes to win the competition. Willie who does not want anything to do with Hilda is reminded that his success will only come if he dances with Hilda. This is a clear reminder that in South Africa, success will only come if the write are united with the blacks. Sam even teases Willie about winning the ball dance with his partner being pillow."Ladies and gentlemen, the winner in the open section... Mr. Willie Malopo and his pillow!" (380) This satirical expression is supposed to discipline Willie. It is only very true that the blacks and whites can only win the battle together and never singly.

Athol Fugard uses absent women characters as dancing partners. One of them is Hilda who Sam suggests for Willie. However, Willie says he feels nothing for her. Sam insists that Willie should pretend and imagine she is not Hilda but another one known as Ginger Rogers. Still Willie doesn't like this one as he says she has no teeth. Sam persuades him to take her all the same because it is only two weeks to the competition and they have to practice. They then settle to another one known as Sarah Vaughan but this one goes for six pence and Willie has only bus fare left. In this heated dialogue, it is evident that Willie will have to do with the wrong partner for the dance.

Athol Fugard is hoping for South Africa and Africa at large with a level ground where all the races are like partners dancing in harmony together in a dancing floor. Sarah Vaughan can dance well but at a price. To get the right partner, Willie has to pay a price. The vision here is that for South Africa to succeed a price has to be paid by the dancers. The dancers are both the blacks and the whites. The price is their commitment to the success of the dance. The climax of the dance is when the winners will be announced. In a dance, there must be two people; a lady and a man. Willie needs to win but he cannot win alone. He must get a partner who will help him to win and not a pillow that has no legs.

Athol Fugard as a playwright has been able to creatively capture the various aspects of the South African life. Through his plays, he has been true to life and also been able to demonstrate the relationship between the social-political environment and the artist. The paywright's plays amazingly remain relevant to post-colonial Africa. A case example is Kenya. Antigone's rare display of bravery is indeed a modern metaphor for many African countries especially Kenya. Kenya's recent historical past just before the last elections speaks of the infamous 'pass law' of electing the 'wanted' leader as prescribed by Big Brother. However, to the astonishment of many, Just like Winston who burned the passbook, Kenyans defied the caution that "Every choice has consequences" and elected leaders whom they believed in. By so doing, they indicated their resentment to the oppressive system of neo-colonialism by loudly proclaiming that "Every consequence has a choice". We are now seeing the resurrection of Pan-Africanism as espoused by the founding fathers of Africa, the Greats like Kwame Nkrumah and Jomo Kenyatta. In terms of gender whatever choices each makes about the other there will always be consequences for or against the other. These in tern will impact on both within there social environment.

\section{Conclusion}

From the discussion of this paper, it is concluded that through drama several gender dynamics can be expressed. This is useful in expressing several social dynamics that affect people in a given society, thus, literature mirrors the society.

\section{References}

Fugard, A. (1974). Hello and Goodbye. New York: Oxford University Press.

Fugard, A. (1976). The Island. New York: Vikings Press.

Fugard, A. (1984). Master Harold and the Boys. New York: Penguins.

Fugard, A. (1987). Blood Knot. New York: Oxford University Press.

Adedoja, E.(2010). Social relevance of African literature to the promotion of social values. Kwara State Polytechnic Ilorin October 2010, 
Volume 7, No.10 Serial No.82), 2010.

Alan, F.(1970). The Turn of the Novel: The Transition to Modern Fiction. London: O.U.P.

Alan, P.(1948). Cry the Beloved Country. New York: Scribner.

Albert B. L.(1975). The Singer of Tales. N.Y.: Atheneum.

Albert, W.(2000) .The Dramatic Art of Athol Fugard. UK: Indiana University Press.

Alex, I. (1964). What Is Sociology? London: Prentice Hall.

Best, S. (2003). A Beginner's Guide to Social Theory. London: Sage Publications.

Blessler,C. (2007). Literary Criticism: An introduction to Theory Practice. $4^{\text {th }}$ Ed.Upper Saddle River: Pearson Education, Inc.

Bolagun, P. O. (2003). Archetypes in African Literary Oral Literary Traditions: an Exampl J. P. Clark's

Brinkerhoff, D., Lynn, K. and Suzanne T. Ortega. (2005) Essentials of Sociology. USA. Wadsworth Publishing Company.

Brutus,S. (1969). The Writers in Modern Africa. $3^{\text {rd }}$ Ed. New York:Africana Publishing Corp.

Caesar, J. (1973). Drama. U.S.A: Scholastic Magazines Inc.

Carrigan, R. (1970). Theatre in the 20th Century. New York: Tulane.

Cassady, and Pat.(1975). Theater and Drama. USA: NTC Publishing Group.

Cass, J. (1967). Literature and Young Children. London: Oxford University Press.

Chatman, S. (1981). Literary Style. London: Oxford University Press.

Dennis, D. and Cosmos Pieterse (1972). African WritersTalking. London:Heineman Educational Books Ltd.

Dennis, W. (2003). Athol Fugard: Writers and Their Work. Britain:North Cote.

Dennis, E. and Cosmos Pieterse.(1972). African Writers Talking. London: Heinneman Educational Books Ltd.

Durosimi, E. and Marjorie Jones. (1996). New Trends and Generations in African Literature. North Cote. London: James Currey.

Edgar, R. (1999). Writing about Literature: Brief 9th Ed. New Jersey: Prentice Hall.

Elegba, A.(2010). Social Relevance of African Literature to the Promotion of Social Values. Ilorin;Kwara State Polytechnic.

Erapu, L. (1977). John Ruganda's The Burdens. Nairobi: Heinemann Educational Books.

February, V. (1981). Mind Your Colour. London: Kegan Paul InternationalLtd.

Fonagy,P. and Target.(2003). Psychoanalytic Theories. New York: Whurr Publications

Fonagy P and Bateman.(2004).Psychotherapy for Borderline Personality. New York: Oxford University Press.

Fonagy,P. and Bateman. (2006). Mechanism of Change in Mentalization based Treatment. United Kingdom: JohnWiley.

Fonagy, P.and Bateman. (2008). Psychoanalytic Constructs. New York: Guilford Press.

Friedman,A.(1970). The Transition of Modern Fiction. London: Oxford University Press.

Gachukia E. (1978). Teaching of African Literature in Schools. Nairobi East African Educational Publishers.

Gergen,K and Mary Gergen. Social Psychology. New York: Hacourt Brace Jovanovich.

Gikandi, S. (1987). Reading the African Novel. London: James Currey.

Goldthorpe, J. (). An I ntroduction to Sociology. London: Cambridge University Press

Gray, S. (1982). Athol Fugard. Johannesburg: Mc Graw-Hill.

Griffith, K. (2006). Writing Essays About Literature: A guide and Style Sheet $7^{\text {th }}$ Ed.USA: Michael Rosenberg.

Guerin, W. etal. (1999). A Handbook of Critical Approaches to Literature. New York: Oxford University Press.

Hacker, D. (1969). Rules for Writers 3rd Ed. NewYork: Bedford Books of St. Martins Press.

Hatch, J. and Ted Shine. (1996). Black Theatre. U.SA: Macmillan Publishers.

Head, D. (1994). Nadine Gordimer. Great Britain: CambridgeUniversity Press.

Hill, E. (1981). The Theatre of Black Americans. Vol. 11. Jersey: Prentice Hall.

Hofer, M.(1981). The Roots Of Human Behaviour. USA:W.H.Freeman\&Company.

Inkels, A. (1964). What is Sociology? London: Prentice Hall Inc.

Kabiru, M. and Anne Njenga.(2009). General Psychology and Personality Development. Nairobi:Acme Press.

Leech, G. and Mick Short. (1981). Style and Fiction. London: Longman.

Lord, A.B.(1975). The Singer of Tales.New York:Atheneum.

Lucas, F. (1955). Style. Great Britain: Cassel and Co. Ltd.

Lyons, J. (1981). Language and Linguistics. Great Britain: Cambridge University Press.

Mahoni ,J. Frank ,B. and Tony Romano. Psychology and You. USA: West Publishing Co.

Maag, J. (2004). Behavioral Management. Canada: WadsworthMcgowan.

Mphalele, E. (1972). Voices in The Whirlwind and Other Essays. New York: Hill and Young.

Mott ,E. P. (1965). The Organisation of Society. USA: Prentice Hall Inc.

Ngara, E. (1982). Art and ldeology in the African Novel. Nairobi: Heinemann.

Nuebeck,K.,Mary Nuebeck and Davita Glasberg.(1979) Social Problem New York: Mc Graw Hill Co.

Norton,P.andJosephEsposito.(1994). TheNewEncyclopediaBritannica.vol28.Chicago :Encyclopedia, Britannica Inc.

Parker, K. (1978). The South African Novel in English. New York: Macmillan.

Paton, A. (1948). Cry the Beloved Country. New York: Scribner.

Peck, J. and Martin Coyle. (1993). Literary terms and Criticism New Ed. London: Macmillan.

Ramage, J., John Ben and June Johnson. (1996). The Allyn and Bacon Guide to Writing. New York: Bedford books of St. Martin's Press.

Rose ,I.. P., Peninah M. Glazer and Myron Peretz Grazer. (1990). Sociology. USA. Prentice Hall. Inc.

Robert, C. (1970). Theatre in the Twentieth Century. New York. Tulane Drama Review. 
Robert, H. Lauler.(2005). Social Problems and the Quality of Life. USA: Mc Graw Hill Co.

Robert, R.K. (2005). Psychology. USA: John Willey \& Son Inc.

Ruby, C. (1969). Currents in Contemporary Drama. London: Indiana University Press.

Ruganda, J. (1992). Telling the Truth Laughingly. Nairobi. East African Educational Publishers.

Scarlyn, N. (1937). European Drama. Great Britain: C. Tringlin \& Co.

Short, M. (1989). A dictionary of Stylistics. London: Longman.

Styan, J. (1993). Modern Drama in Theory and Practice 3. New York: Britain: Jonathan Cape.

Styan, J. (1993). The Elements of Drama. New York: Cambridge University Press.

Thompson, J. (1982). Sociology. England: Clay Ltd.

Tyson L. (2005). Critical Theory Today. New York: Rout ledge.

Wa Thiong'o, N. (1991). Moving the Centre. Nairobi: Heinemann Educational Books.

Wanjala, C. (1973). Standpoint on African Literature. Nairobi East African Literature Bureau.

Wellek,R.andAustinWarren.(2000). TheoryofLiteratureBritain:JonathanCape. Wertheim, A. (2000). The Dramatic Artof Athol Fugard. UK: Indiana University Press.

William, R. (1968). Drama in Performance. Great Britain: Alden and Mow.

Wilson, N.S. (1937). European Drama. Great Britain: C. Trinling\&Co. 